\title{
On Robust Discursive Equality
}

\section{THOMAS M. BESCH Wuhan University}

ABSTRACT: This paper explores the idea of robust discursive equality on which respect-based conceptions of justificatory reciprocity often draw. I distinguish between formal and substantive discursive equality and argue that if justificatory reciprocity requires that people be accorded formally equal discursive standing, robust discursive equality should not be construed as requiring standing that is equal substantively, or in terms of its discursive purchase. Still, robust discursive equality is purchase sensitive: it does not obtain when discursive standing is impermissibly unequal in purchase. I then showcase different candidate conceptions of purchase justice, and draw conclusions about the substantive commitments of justificatory reciprocity.

RÉSUMÉ : Cet article explore l'idée d'égalité discursive robuste sur laquelle reposent bien souvent les conceptions de la réciprocité justificative basées sur le respect. Je distingue l'égalité discursive formelle et substantive en estimant que si la réciprocité justificative requiert que les interlocuteurs bénéficient d'une posture discursive égale du point de vue formel, une égalité discursive robuste ne devrait pas être comprise comme exigeant des postures discursives substantivement égales, ni être envisagée dans les termes de son poids discursif ("discursive purchase»). Toutefois, l'égalité discursive robuste est sensible aux poids des discours: elle est absente lorsque le poids des discours est manifestement inégal. Je montre ensuite différentes conceptions possibles de la justice en termes de poids discursif et je tire des conclusions sur les engagements substantifs de réciprocité justificative.

Keywords: discursive equality, public justification, reciprocity, inclusion, discursive standing, Rainer Forst, reciprocity and generality

This discussion explores the idea of discursive equality that respect-based conceptions of justificatory reciprocity often build on, or aim to model. To specify my topic and the angle from which I approach it, I begin by locating this idea in a familiar line of thought that proponents of such conceptions sometimes invoke.

According to this line of thought, we should equally respect relevant people-or, say, their equal right to justification, their autonomy, their freedom, their capacity for reasons, or their robust moral selfhood ${ }^{1}$-in a way that finds expression not only in the content of justice, such as the substantive rights, liberties, and opportunities that just social structure allocates people, but that reflects, as well, in the standards of moral or political justification. Specifically, these standards must accord people a normative say that is equal and robust in justification. In terms of a slogan, each relevant person must be respected not just as an equal recipient or equal client of justification, but as an equal co-author or equal authority of justification ${ }^{2}$-so that duly justifiable moral or political arrangements can apply to them

\footnotetext{
1 See Forst (2010), p. 719; Forst (2012), p. 21, 212; Forst (2011); Macedo (1991), p. 46f; Larmore (2015), p. 79; Postema (1995), esp. pp. 76-85.

2 Forst (2017), p. 134.
} 
"in their name,"3 or in a way that treats each as an "indivisible part of the whole." ${ }^{4}$ Thus, the idea goes, we must adopt justificatory reciprocity: moral or political justification must take the form of a constructivist, robustly public ${ }^{5}$ justification that regards some form of equal acceptability by relevant people as justifying.

For one example, take Rainer Forst's constructivism - which I will use here as a proxy for views of justificatory reciprocity. He ties discursive equality to a comprehensive form of justificatory reciprocity. Proper respect for people, or for their equal right to justification, is here taken to require that all moral or political "normative claims" be justifiable by a standard of reciprocal and general acceptability (RGA): 6

RGA $\phi$ is valid, or justified, if and only if $\phi$ is, or is based on reasons that are, equally acceptable (reciprocity) by all affected people (generality). ${ }^{7}$ (Forst supposes that reciprocal and general acceptability must also be "reasonable." 8 )

As Stefan Gosepath puts the point, "[o]nly that which is equally acceptable to everyone can be regarded as justified." 9 For Forst, the standard of "reciprocal-general justification"10 applies to relevant normative claims at all levels of thought or argument. And so it applies, as well, to RGA itself and whatever moral or political normative claims are needed to specify or flesh out RGA's content. 11

Other approaches tie discursive equality to non-comprehensive forms of justificatory reciprocity. A seminal example is Rawls-type political liberalism. For political liberals, proper respect for reasonable people, or their freedom and equality, calls for a form of constructivism that requires equal acceptability only of political principles, values, or reasons. ${ }^{12}$ A reason, $\phi$, for a moral or political arrangement here counts as a public reason only if $\phi$ is equally acceptable as such a reason by all reasonable people, while justifications count as politically authoritative, public justifications only insofar as they justify by public reasons. ${ }^{13}$ Thus, here, too, an idea of equal respect finds expression in a commitment to

3 Nagel (2005), p. 121.

4 Rousseau (1988), p. 93.

5 Postema (1995).

6 Forst (2012), p. 214; Forst (2017), pp. 1-36.

7 See Forst (2012), p. 214.

8 Forst (2012), p. 21; Besch (2015); Besch (2018c).

9 Gosepath (2015), p. 133.

10 Forst (2017), p. 4.

11 By referring to Forst's view as an example of a respect-based conception of justificatory reciprocity, I do not deny that Forst appeals not only to an idea of equal respect-i.e., moral respect for people's equal right to justification-as a basis for his conception of justificatory reciprocity. For example, he also appeals to the validity claims of moral or political normative claims. Yet his argument from moral respect is more fundamental systematically and up to a point more promising: see Besch (2015).

12 See Macedo (1991), p. 46f; Larmore (2015), p. 74-80; Rawls (2005), lecture III. Macedo and Larmore are perhaps most upfront about the grounding role of an idea of respect for political liberalism's view of public justification.

13 On reasonableness in political liberalism, see Larmore (2015), p. 72ff; Mandle (1999); Enoch (2015), pp. 
justificatory reciprocity.

However, what does it take to accord real people-as opposed to idealizations of people, or hypothetical model agents - the standing of equal co-authors or equal authorities in actual, non-ideal justification? What, in actual justification, constitutes a robust and equal normative say? This is what I explore here. To further fix ideas, let me preview one reason why this is a vexing topic-this will help, as well, to identify the angle from which I approach matters.

Consider first that all conceptions or practices of acceptability-based justification must qualify the kind of acceptability that they regard as justifying: for equal acceptability to justify, it must also be respectable, or authoritative - for example, it must be reasonable, rational, epistemically responsible, and so on. Hence, robust discursive equality must be seen in light of the thresholds or constrains of authoritativeness that conceptions or practices of justificatory reciprocity adopt (to simplify, I put things here in terms of thresholds of, or bars for, authoritativeness).

This can complicate things. A conception or practice of justificatory reciprocity can consistently apply its standards, such as its bar for authoritativeness, to all relevant people and still fail to treat them as discursive equals, or to model robust discursive equality, if these standards relate to these people in the wrong way. And they relate to these people in the wrong way if they accord them discursive standing that is impermissibly unequal in discursive purchase (for now, we can think of discursive purchase as the measure of normative influence that an agent has in justification). Yet it is not clear what it takes for such standards to relate to people in the right way, or when allocations of discursive purchase are not impermissibly unequal.

One of my aims, then, is to explore when standards of justificatory reciprocity relate to the people they range over, or apply to, in the right way-i.e., a manner that coheres with the kind of discursive equality that justificatory reciprocity builds on, or tries to model. This helps to bring out that justificatory reciprocity is richer in ethical suppositions and commitments than many proponents of justificatory reciprocity seem prepared to allow. In a nutshell, justificatory reciprocity requires purchase justice. That is, practices of justificatory reciprocity are reasonable only if they do not allocate discursive standing of impermissibly unequal purchase. But there is no agreement as to what constitutes purchase justice. And while there can be many pro tanto plausible conceptions of purchase justice-below, I sample five candidates - it is far from clear what conception we may adopt, or on what grounds we may do so. This is troublesome news for proponents of justificatory reciprocity.

As to the angle from which I approach my topic, I focus on one of the less prominent respectability dimensions of public justification-or of acceptability-based moral or political justification, for that matter. Prominent dimensions include output respectability (for example, can such justification yield results that are true, plausible, or useful?), input respectability (for example, does it count the right kind of discursive input as authoritative?), and the respectability of justification procedure (for example, does it arrive at its results in the right way?). However, my focus is on the respectability of the relationship between the standards of justification and the people they range over, or apply to. Specifically, I focus on what we might call the participation value of public justificationwe might also refer to it as its emancipation or non-domination value. The question here is whether relevant standards of justification, such as bars for authoritativeness, allocate 
relevant people a respectable measure or kind of normative influence in justification, or on its outcomes.

Why adopt this angle? It is salient here. Where theorists foreground ideas of discursive equality, they often attach much importance to the participatory or emancipatory role of justification. Forst's work is a case in point. Throughout his writings, he assumes that RGA, his standard of reciprocal and general acceptability, accords people a genuine measure of normative influence in justification. Specifically, he takes RGA to accord people a "qualified veto-right"14 that helps to protect them from unacceptable impositions, domination, or the disrespect that comes with this. And it is on this basis that he takes RGA to be at the core of many important things, such as a reconciliation of authority with freedom and equality, political legitimacy, or a basic structure of justification that enables fundamental justice, real democracy, or true non-domination. ${ }^{15}$ Yet there is little in his work that accounts for RGA's presumed participation value. And Forst is not alone with this. Arguably, political liberals like John Rawls, Stephen Macedo, and Charles Larmore attach importance to the participation value of public justification-this is reflected in their commitment to a form of public justification that accords reasonable people discursive standing of much discursive purchase. ${ }^{16}$ But they, too, leave the participation value of public justification systematically underdeveloped. At any rate, once we explore this value more systematically, it quickly becomes problematic how equal acceptability justification can model robust discursive equality-or so we shall find.

I proceed as follows. Section 2 puts into place tools that I need to explore my topic. I elaborate on "co-authorship" in justification, constitutive discursive standing, and discursive purchase. The remainder of my discussion is then organized around two questions:

Q1 Does robust discursive equality require that relevant people have discursive standing that is equal in discursive purchase?

Q2 If robust discursive equality does not require equal discursive purchase, when is purchase permissibly unequal?

Q1 takes centre stage in Section 3. I distinguish between formal and substantive discursive equality and suggest that if justificatory reciprocity requires that people be accorded formally equal discursive standing, then robust discursive equality should not be construed as requiring standing that is equal substantively, or in terms of its purchase. Still, it is purchase sensitive: robust discursive equality does not obtain when purchase is impermissibly unequal. This sets the stage for a discussion of Q2, which takes centre stage in Sections 4, 5, and 6.

Q2 is a hard question, and one of my aims here is to highlight its importance in matters of justificatory reciprocity. To this end, I showcase five pro tanto plausible candidate conceptions of the permissibility of purchase inequality-i.e., what I called earlier conceptions of purchase justice. Each candidate adapts a more general view of justice to the case of allocations of discursive purchase. Section 4 considers discursive versions of Rawls's difference principle and his view of fair equality of opportunity. Section 5 considers a form

14 Forst (2001), p. 168f; Forst (2010), p. 719.

15 Forst (2017), pp. 131-137.

16 Besch (2012); Besch (2018a). 
of perfectionism and a variant of sufficientarianism. Section 6 adapts Amandine Catala's and Miranda Fricker's views of epistemic justice to the case at hand. Section 7 concludes by bringing out implications for justificatory reciprocity.

\section{Discursive Standing}

What does the standing as a co-author or an authority of justification involve? It seems to involve at least two things. First, of course, it involves a normative say that plays a robust role in justification-specifically, it involves a form of constitutive discursive standing. And second, this say must also be meaningful, or have a relevant degree of discursive purchase. I address both points in turn, starting with constitutive discursive standing.

If a justification practice, JP, accords (actual or possible) people constitutive discursive standing in relation to $\phi$ (e.g., a principle, value, reason, or arrangement), JP does two things. First, JP attaches positive value to $\phi$ 's authoritative acceptability by these people. Second, JP takes it that $\phi$ depends for its justification, or validity, on its authoritative acceptability by these people. For example, when relevant people authoritatively accept $\phi$, JP counts this as (defeasible) evidence for $\phi^{\prime}$ 's justifiability; or when they authoritatively disagree with, object to, or reject $\phi$, JP counts this as (defeasible) evidence against $\phi^{\prime}$ s justifiability. Constitutive discursive standing contrasts with weaker, derivative discursive standing. When JP accords people derivative standing vis-à-vis $\phi$, then JP attaches value to $\phi$ 's acceptability, but it does not take $\phi$ to depend for its authority on its acceptability. Where people have derivative standing, they are recipients or clients, but not also coauthors or authorities of justification. 17

Conceptions or practices of justificatory reciprocity prescribe that constitutive discursive standing be accorded to every agent who they include on fully enfranchised footing in what they regard as the (primary) constituency of justification. It is not always clear what agents are being accorded that standing in a given justification practice. For what matters here, however, we may simplify. Given a justification practice, again referred to as 'JP,' a bar for authoritativeness, $\psi$, and a group of (actual or possible) agents, $G$ : if JP counts $\phi$ as justified, or valid, only on the condition that $\phi$ is $\psi$-acceptable, or $\psi$-non-rejectable, by each member of $G$, then JP accords each member of $G$ constitutive discursive standing.

On the other hand, co-authorship in justification involves a normative say that is not merely notional or symbolic, but meaningful: it must be able to bring to bear an agent's voice, or her perspective, in justification, or on its conclusions. At least three things seem necessary for this. To start with, (i) accessibility: people must be able to exercise what justification practice recognizes as an authoritative say. Take again Forst's RGA, the standard of reciprocal and general acceptability. For Forst, RGA accords people a "qualified vetoright" that helps to protect them from unacceptable domination. But to be of such use, it must be within people's actual reach to carry out what RGA counts as an authoritative exercise of that right. Next, (ii) a normative say must also be authentic. What justification counts as an agent's authoritative say must track, or not distort, her voice, or perspective. For example, suppose Paul is committed to reject $\phi$ (and so rejects $\phi$ ), but it is also true that he would not reject $\phi$ if he was ideally rational (which he is not). If RGA then attributes to Paul that $\phi$ is acceptable by him-say, because RGA only considers what people would reciprocally and generally accept if they were ideally rational-then what counts as Paul's authoritative say would not recognizably be his say, or not by his lights. Not least, (iii) a

On constitutive and derivative discursive standing, see Besch (2014). 
normative say must be effective: it must exert some normative influence in justification. For example, if Paul authoritatively rejects $\phi$, this must count as (defeasible) evidence that $\phi$ is not suitably justifiable, or that there is reason to doubt $\phi$, or that $\phi$ stands in need of (further) justification, and so on.

Together, the accessibility, authenticity, and effectiveness of an agent's normative say determine its discursive purchase. What is that? Roughly, discursive purchase is a matter of the normative influence that an agent's discursive standing accords the agent in justification, or on its outcomes, given her actual deliberative resources-widely conceived so as to include the entire range of views, volitions, interests, deliberative or doxastic norms, policies, skills, or capacities that she actually draws on in her actual practical reasoning. Discursive purchase so construed is indexed to people as they are. It is not indexed to idealizations of people, ideal people, or hypothetical agents. When we consider discursive purchase, what we consider is how standards of justification relate to actual people, and what level of normative influence in justification, or on its outcomes, these standards accord these people, given their actual deliberative resources. 18

To make this more intuitive, and to consider degrees of discursive purchase, consider the example of two justification practices, JP1 and JP2. Each accords average Betty a robust normative say, or constitutive discursive standing. JP1 adopts a low-idealization bar for authoritativeness that average adults readily meet. JP2 adopts a high-idealization bar for authoritativeness that average adults never actually meet. As a result, Betty's normative say significantly varies in discursive purchase:

JP1 $\phi$ is valid if and only if no relevant person can authoritatively reject $\phi$. Betty's acceptance or rejection of $\phi$ is authoritative if and only if it is locally coherent in light of Betty's actual deliberative resources.

JP2 $\phi$ is valid if and only if no relevant person can authoritatively reject $\phi$. Betty's acceptance or rejection of $\phi$ is authoritative if and only if it is ideally rational (or: if and only if Betty would still reject $\phi$ if she was ideally rational).

In JP1, Betty can exercise influence in justification. She is able to exercise an authoritative say. And her say is both authentic and effective: if she cannot actually accept $\phi$ coherently, JP1 counts this as evidence that $\phi$ is not justified, or valid. Thus, Betty's discursive standing is high in discursive purchase. Not so in JP2. In JP2, what has normative influence is an ideally rational say. But suppose Betty is unable to exercise an ideally rational say, and that her actual say is not aligned with an ideally rational say. In this case, Betty's actual say does not count toward $\phi$ 's justification status. Thus, her standing is low in discursive purchase.

Earlier, I said that accessibility, authenticity, and effectiveness determine discursive purchase: rendering an authoritative say less accessible, less authentic, or less effective diminishes its purchase. For example, if justification practice sets its bar for authoritativeness very high, like JP2, it may put the exercise of an authoritative say out of people's actual reach. Or if what justification counts as an agent's authoritative say mismatches her actual voice, it may not actually give her any real influence in justification. 19

18 See Besch (2014); Besch (2018b).

19 As I argue elsewhere, there is a correlation between the idealization value of standards of justification and the degree of discursive purchase they can allocate: high idealization values entail low degrees of purchase 
The notion of discursive purchase draws attention to the value or use that an agent's discursive standing can have for her. And some such category is needed to bring out that instantiations of discursive standing of the same kind, such as Betty's constitutive discursive standing in JP1 and in JP2, can come with different degrees of normative influence in justification, and hence can vary in its value or use for the agent. For what matters here, I shall assume that an agent's discursive standing increases in its value or use as it increases in its discursive purchase, other things being equal. I assume, as well, that discursive standing that is meaningfully high in purchase-or high-purchase discursive standing -is a good. Specifically, I will think of it as a soft kind of primary good, or an inclusive enabler good: a good that we value, or have reasons to value, and that helps to protect and support the pursuit of a wide (but not unlimited) range of conceptions of what is good, right, or true. 20 (Readers who disagree with the view that high-purchase discursive standing is an inclusive enabler good can bracket it so long as they grant that it is a good, or that it reasonably matters to relevant people.) I set aside the question of how high in purchase discursive standing must be for it to be meaningfully high-yet I assume that high-purchase discursive standing is more like Betty's standing in JP1 than Betty's standing in JP2. I also set aside the question of why high-purchase discursive standing is a good (but I address the issue elsewhere). 21 What I want to focus on now is what it would mean for a robust normative say, or constitutive discursive standing, to be equal.

\section{Discursive Equality: Formal, Substantive, Purchase Sensitive}

From the above, it is clear that discursive standing can be equal in more than one respect. Consider two claims (for a justification practice, JP):

1. JP consistently applies all relevant standards, such as its bar of authoritativeness, to all relevant people (or JP fails to do so).

2. In JP, each relevant person has an equally meaningful normative say, or discursive standing of equal discursive purchase (or this is not so in JP).

The difference between (1) and (2) motivates a distinction between formal and substantive discursive equality (for two individuals, $A$ and $B$ ):

FE JP accords $A$ and $B$ formally equal discursive standing if and only if (i) JP accords $A$ and $B$ discursive standing of the same type (e.g., constitutive discursive standing), and (ii) JP applies to $A$ and $B$ the same authoritativeness threshold.

SE JP accords $A$ and $B$ substantively equal discursive standing if and only if their respective discursive standing has equal discursive purchase.

Formal and substantive discursive equality can come apart. The discursive purchase of the

and high degrees of purchase require low idealization values. This may be one reason why conceptions of public justification that attach importance to the participation value of public justification tend to idealize less, rather than more. See Besch (2018b).

20 On Rawls-type primary goods, see Rawls (2001), p. 60. These are all-purpose goods of which all rational persons want more. If there are any such goods, high-purchase discursive standing is probably not one of them. It is not necessarily irrational to refuse increases of our normative influence in justification if we take it, for example, that valuable degrees of such influence cannot exceed a certain level.

21 See Besch (2014); Besch (2018b). 
standing that JP can accord to relevant people depends on various factors, including (i) its bar for authoritativeness and (ii) their actual deliberative resources. And JP will accord discursive standing that is equal formally but not also substantively when people relevantly differ in their deliberative resources. For example, take a third justification practice, JP3:

JP3 $\phi$ is valid if and only if $\phi$ is authoritatively acceptable by all relevant people. Every relevant person has discursive standing of the same kind, and the same bar for authoritativeness, $\psi$, applies to all.

JP3's constituency includes Gifted Group and Limited Group. Members of Gifted Group always meet $\psi$ anyway, given their actual deliberative resources. Members of Limited Group never fully meet $\psi$, given their actual deliberative resources. Members of Gifted Group have high-purchase discursive standing like Betty in JP1; members of Limited Group have lowpurchase standing more like Betty in JP2.

JP3 allocates relevant people discursive standing that is equal formally but not also substantively. As a rule of thumb, formally equal discursive standing will not be substantively equal where relevant people relevantly differ in their actual deliberative resources. In what follows, I assume that the kind of discursive equality justificatory reciprocity builds on, or models, requires formal discursive equality. However, does it require formal equality only?

Intuitively at least, robust discursive equality requires more than formal discursive equality. Consider another justification practice, JP4:

JP4 $\phi$ is valid if and only if $\phi$ is authoritatively acceptable by all relevant people. Every relevant person has discursive standing of the same kind, and the same bar for authoritativeness, $\psi$, applies to all.

JP4's constituency includes Dominant Group and Marginal Group. Over time, Dominant Group has used its influence to define $\psi$ in terms of values that it accepts and Marginal Group rejects: JP4 recognizes discursive input as authoritative if and only if it is compatible with the values of Dominant Group. Accordingly, members of Dominant Group have high-purchase standing like Betty in JP1, and members of Marginal Group have lowpurchase standing more like Betty in JP2.

JP4 meets formal equality: it accords to all constitutive discursive standing and applies $\psi$ throughout. But JP4 does not situate members of Dominant Group and members of Marginal Group as discursive equals. Rather, JP4 accords a full normative say only to Dominant Group, thus entrenching its dominance over Marginal Group. In fact, in JP4, justification itself seems to turn into a vehicle of domination, marginalization, or worse. The point: formal discursive equality can conceal problematic discursive inequality. (Below, I repeatedly return to JP4 as an example of a problematically unequal justification practice.)

This suggests that we understand robust discursive equality in terms that are purchase sensitive. Consider Equality Purchase Sensitive (EPS):

EPS JP accords to $A$ and $B$ equal discursive standing if and only if (i) JP applies to $A$ and $B$ discursive standing of the same type, and (ii) JP applies to $A$ and $B$ the 
same authoritativeness threshold, and (iii) $A^{\prime}$ s and $B^{\prime}$ s respective discursive standing is not relevantly unequal in discursive purchase.

In conjunction, (i) and (ii) state a condition of formal discursive equality. (iii) states a negative condition of substantive discursive equality. According to EPS, equal discursive standing need not be standing of equal purchase if it does not relevantly differ in purchase. This has considerable appeal-although it is not quite informative so long as it remains open when purchase inequality is relevant.

When is purchase inequality relevant? Part of an answer is surely this: differences in purchase are relevant when they are not permissible. I showcase views of the permissibility of purchase inequality below. For now, consider Discursive Equity (DE), a view to the effect that purchase differences are never permissible, and hence are always relevant:

DE Discursive equality requires formal and substantive equality of discursive standing.

I want to suggest now that we set aside DE for the purposes of actual justifications between actual people-although DE can still inform an ideal conception of justificatory reciprocity.

First, ideal justification might assume away purchase-relevant interpersonal difference by positing near-identical, normalized, ideal model agents-to such agents, ideal justification can accord formal and substantive discursive equality. But actual justification occurs in contexts of interpersonal difference, and the more inclusive in scope it becomes, the more such difference is included within its scope. People always differ in their deliberative resources, and these differences often impact significantly how accessible it is for them to meet non-trivial authoritativeness thresholds-thresholds, that is, that not every relevant person always meets anyway. When justification builds on such thresholds, some differences in purchase seem inevitable.

Second, we have reasons not to build actual justification by a standard of justificatory reciprocity on a trivial authoritativeness threshold-one that all relevant people always meet anyway. Consider a principle that prohibits marital rape. I take it that if a standard like Forst's RGA filters out such a principle as invalid, then the standard cannot plausibly serve as a standard of justification. Yet a prohibition of marital rape is not equally acceptable by every affected person in light of their actual deliberative resources. Some husbands are committed rapists: they see it as their role prerogative to force their spouses to have sex. But then the principle in question would fail the test of justificatory reciprocity. A parallel case would hold for a principle that permits marital rape. You and I would be unable to accept the principle. Marital rape would hence be neither prohibited nor permitted. Similar incoherence results would ensue for all relevantly contested moral content. 22 The general point at hand here is familiar. Inclusive actual justification between actual people by an unqualified "equal acceptability" standard leads to incoherence or anomy. 23 Thus, ideal theory aside, premising standards of justificatory reciprocity on trivial bars for authoritativeness is not an option.

The first of the two questions asked earlier, Q1, was this: does robust discursive equality require that relevant people have discursive standing that is equal in discursive

22 See Steinhoff (2015), p. 168.

23 See Enoch (2015), p. 117f; see also Besch (2018a). 
purchase? The above suggests a negative (albeit nuanced) answer. Setting aside ideal theory and hence focusing only on actual justification between actual people: if justificatory reciprocity requires formal discursive equality, then robust discursive equality should not be taken to require substantive discursive equality, or equal purchase. However, robust discursive equality is purchase sensitive.

\section{Permissible Purchase Inequality?}

This brings us to Q2, the second question asked earlier: if robust discursive equality does not require equal discursive purchase, when is purchase permissibly unequal?

To make headway with this question, I make two assumptions. The first is already implicit in the above: a justification practice that satisfies formal equality can set its bar for authoritativeness higher or lower, at more or less idealizing levels relative to the deliberative resources of relevant people. Hence, it can accord none, all, or only some people the good of high-purchase discursive standing. Second, this good behaves like a transparent allocative good in at least some relevant cases. Where it does behave like this, we can allocate this good to people, or access to it, and we can tell whether they have (more or less) access to it.

With this in place, Q2 begins to look like a question of distributive justice-a question about the permissibility, or justness, of an unequal allocation of a relevant good, namely, the good of high-purchase discursive standing. However, it is not an ordinary, firstorder question of the kind. To settle such questions, we must draw on first-order principles (norms, conceptions, standards) of justice-assuming a commitment to justificatory reciprocity-that depend for their justification, or validity, on their equal acceptability by relevant people. But Q2 concerns a condition of the reasonableness of standards of justificatory reciprocity. It cannot be reasonable to use such a standard in justification if that standard allocates discursive purchase impermissibly, or unjustly. The point: constraints on allocations of discursive purchase constrain what content may be built into standards of justificatory reciprocity. As such, they mark conditions of the reasonableness of such standards. Hence, the matter at hand is a higher-order matter of distributive justice (I return to this later).

Now, there can be many conceptions of the permissibility of purchase inequality-or conceptions of purchase justice, for short. I shall now showcase five candidate conceptions. Each candidate adapts a more general view of justice to the specific matter at hand, and each has at least some initial appeal. I will not attribute them to anyone, as they mark possibilities rather than established positions. Nor will I argue for or against any one candidate. My main aim is exploration; each candidate has resonance in the literature, puts different content into the idea of purchase justice, and highlights different aspects of the contours of the theme. This helps to draw out substantive commitments of justificatory reciprocity. It is also of independent interest: each candidate tracks different intuitions of purchase justice, and each marks a different dimension in which a conception of purchase justice might be developed. I restrict my focus to candidates that are compatible with formal discursive equality and the view that equal authoritative acceptability can justify in at least (some) moral or political matters.

The first two candidates echo Rawls's conception of justice. To start with, consider a Discursive Difference Principle (DDP):

DDP Purchase inequalities are permissible within a justification practice if and only 
if they are to the greatest relevant benefit of the discursively least influential relevant people.

A view like this has some prominence. As James Bohman notes, deliberative democrats "generally argue for an epistemic form of Rawls's difference principle: that good deliberative practice ought to maximize deliberative inputs, whatever they are, so as to benefit all deliberators, including the least effective." 24 This resonates with DDP if we take it to refer to a deliberative form of the principle (rather than a form that is epistemic in a narrow, strictly truth-aiming sense).

To illustrate, revert to JP4, the problematically unequal justification practice that we saw in Section 3, above: JP4 accords formal discursive equality to all relevant people, including members of Dominant Group and members of Marginal Group, but fails to situate them as discursive equals as the values of Dominant Group are defined into its bar for authoritativeness. Suppose we take an allocation profile of purchase inequality to be 'to the greatest relevant benefit' of JP4's group of 'discursively least influential relevant people' if its bar for authoritativeness accords typical members of JP4's Marginal Group a higher level of discursive purchase than all eligible alternative allocations. For simplicity's sake, let there be only one such alternative, i.e., a bar not biased toward Dominant Group, and assume that JP4, if it adopts this bar, accords members of Marginal Group a higher level of purchase. DDP would thus require that JP4 adopt that bar. Of course, there can be other readings of DDP. For example, there can be many views of what makes a group discursively least influential or of what counts as their greatest relevant benefit, and such benefits need not come in the form of increases of the discursive purchase of their discursive standing.

A second candidate is Discursive Fair Equality of Opportunity (DFO):

DFO Purchase inequalities are permissible within a justification practice if and only if each relevant person in this practice has a fair chance to access discursive standing of a relevantly high level of discursive purchase. 25

This has some initial appeal, too. For example, intuitively, it is not improper that Betty has lesser discursive influence in justification than she could otherwise have if this is owed in essential part to her informed choice not to undertake whatever efforts are needed to qualify for more purchase-say, by trying harder to meet a relevant bar for authoritativeness-provided she has a fair chance to succeed with such efforts were she to undertake them.

DFO allows for many variants depending on, for example, what we count as a 'relevant' level of discursive purchase or as constituting a 'fair chance' to access purchase of that level. At any rate, we saw above that the level of discursive purchase that a justification

24 See Bohman (2006), p. 175, 178ff; see also Karpowitz and Raphael (2016), Art. 3. Bohman sees the point of the principle as a matter of widening deliberation's scope of inclusion. My present focus goes further. Recognizing people or their inputs as relevant for deliberation, or justification, is one thing. But according them or their inputs suitable discursive purchase is another. When the former comes without the latter, inclusion can be hollow: widening the scope of inclusion does not ensure that then-included people can suitably bring to bear their voices. For this, their standing must also have due purchase.

25 Rawls (2001), p. 44ff. DFO is distinct from Cohen's principle of "equal opportunity for political influence" and to "reshape both the terms of political debate and its results" that is at the heart of Cohen's participatory view of democracy. Yet it evidently sits well with it. Cohen (2006), p. 242. 
practice can allocate to relevant people depends on (i) its bar for authoritativeness, and (ii) their actual deliberative resources. Thus, if deliberative input counts as authoritative only if it exhibits a high level of epistemic responsibility, then epistemically highly responsible Betty can access discursive standing of higher purchase than epistemically irresponsible Paul. His standing can increase in purchase, accordingly, if the bar for authoritativeness is lowered so as to require relevantly lower levels of epistemic responsibility, or if he becomes epistemically more responsible. The presence of a fair chance to access discursive standing of relevant purchase can hence be construed in terms of (i) or (ii), or both.

Consider first (ii). Suppose a justification practice is embedded in social structure that unfairly denies Paul access to "epistemic goods"26 (e.g., education, good information) that are necessary to develop to a level of epistemic responsibility that would allow him to meet JP's bar for authoritativeness. Other things being equal, then, this justification practice would violate DFO. As to (i), above, revert again to the problematically unequal justification practice JP4. JP4's bar for authoritativeness from the outset accords dominating weight to the commitments of typical members of Dominant Group. Assume that this makes discursive standing of relevant purchase accessible to them, but not to members of Marginal Group. Thus, other things being equal, JP4 would violate DFO.

In passing, I set aside Rawls's "general conception" and his "liberty principle" as they are not helpful here. The general conception is the view that all "social values ... are to be distributed equally unless an unequal distribution of any, or all, of these values is to everyone's advantage." 27 On a self-suggesting discursive reading, this requires an allocation of formally and substantively equal discursive standing unless a different allocation is relevantly advantageous. But what matters here is purchase inequality that may obtain while formal discursive equality obtains. At the same time, this view would implausibly take it that substantively equal discursive standing is an available option. Perhaps all that we can take away from Rawls's general conception is the suggestion that purchase inequality must be to the advantage of all. And this does not help: advantages that arise via purchase inequality are permissible only if this inequality is permissible-which leads back to the question we are now considering. As to the liberty principle, it is the view that "each person has an equal claim to a fully adequate scheme of equal basic rights and liberties." 28 On a discursive reading, this might require that people be accorded standing of fully adequate purchase. But this, too, does not help if we plausibly take it that any given level of purchase is adequate only if it is compatible with relevant permissibility constraints.

\section{Resource Perfectionism and Sufficiency Necessary}

The third and fourth candidates are perfectionist and sufficientarian, respectively. To start with perfectionism, in considering the permissibility of purchase inequality, we might focus not primarily on how high or low a justification practice sets its bar for authoritativeness, but on whether it is embedded in social structure that enables people to acquire a suitably high level of deliberative resources. This suggests Resource Perfectionism (RP) (for social structure, $S$, in which a justification practice, JP, is embedded):

\footnotetext{
26 Fricker (2013), p. 1317.

27 Rawls (1972), p. 62.

28 Rawls (2005), p. 5.
} 

each relevant person to a desirably high level of deliberative resources, or the highest viable approximation thereof.

RP allows for many variants, but the main idea is plain. Suppose JP requires a high level of deliberative resources-e.g., intellectual skills, relevant background information-that people typically acquire or maintain only through third-party efforts, e.g., education, special training, openly available high-quality information, or other forms of social support or thirdparty input. Suppose also that JP is embedded in social structure-say, cultural, moral, political, or other practices, norms, or institutions - that may or may not provide people with the support or input they need to develop or maintain their deliberative resources. Thus, RP would have it that purchase inequality in JP is permissible only if social structure is arranged so as to provide each relevant person with the relevant support or input.

RP aligns with some perfectionist ideas of democracy. Consider Robert Talisse's epistemic perfectionist view, and the idea of "responsible epistemic agency" at its core. 29 For Talisse, "the democratic state must take positive steps to enable proper epistemic agency and to discourage epistemic vice," 30 and so it must address social, political, economic, cultural, and other obstacles to the development or exercise of such agency. Thus, it must institute "norms of equality, free speech, freedom of information, open debate, protected dissent, access to decision-making institutions, access to public education," as well as norms "that promote participation, inclusion, and recognition."31 Democracy so understood essentially involves epistemically respectable practices of reasongiving between epistemically responsible citizens. This sits well with RP. The capacity of agents to authoritatively participate in practices of reason-giving of the sort involved in epistemic perfectionist democracy depends, as well, on social structure that supports the development of their deliberative resources. RP thus suggests that citizens may have unequal normative influence in epistemic perfectionist democracy's practices of reasongiving, or on the outcomes of such practices, only if there is social structure that permissibly lifts them to a suitable level of deliberative resources.

Turning next to a sufficientarian view, we might adapt to the case at hand Harry Frankfurt's intuition that when inequality matters morally, this is often not because there are people who have less than others, but because the people who have less do not have enough. 32 This suggests Sufficiency Necessary (SN):

SN Purchase inequality within a justification practice is permissible if and only if each relevant person has discursive standing of sufficient discursive purchase.

This, too, has initial appeal-assuming a suitable conception of purchase sufficiency can be supplied. Such conceptions can come in at least two kinds:

(i) Maximalist purchase sufficiency: a person's discursive standing has enough

29 Talisse (2007), p. 63; see also p. 66 and pp. 70-75.

30 Ibid., p. 72.

31 Ibid.

32 See Frankfurt (1987), esp. pp. 34-41; Frankfurt (2015), pp. 43-61. 
discursive purchase for her to access relevant goods. If her discursive standing gave her more normative influence in justification, this would not add relevant positive value.

(ii) Minimalist purchase sufficiency: a person's discursive standing has enough discursive purchase for her to avoid relevant bads. If her discursive standing gave her less normative influence in justification, she would not be able to do, bring about, or avoid, what it would be relevantly bad not to be able to do, bring about, or avoid.

Variants of SN will differ depending on whether they adopt maximalist or minimalist conceptions of purchase sufficiency and on what they construe as sufficiency-relevant goods or bads. 33

Revert again to the problematically unequal justification practice JP4, above. As we have seen, its allocation of discursive standing is problematic. Yet as far as discursive equality is concerned, the problem cannot be merely that members of Dominant Group have standing of more purchase than members of Marginal Group. Perhaps, then, the problem is that JP4 accords the latter standing that is low enough in purchase to expose them to relevant bads. For example, since JP4 counts their deliberative input as authoritative only if it coheres with key commitments of members of Dominant Group, they might be unable to effectively contest these commitments; or it might render them vulnerable to domination. And, of course, by exposing them and only them to these bads, JP4 fails to duly respect or recognize their equality-despite according them formally equal discursive standing.

In passing, there is considerable affinity between $\mathrm{SN}$ when it builds on minimalist purchase sufficiency and the view that justificatory reciprocity should have a protective function if we add two things. First, moral or political arrangements (or other things) must be justifiable to relevant people by standards that accord them meaningful rejection rights. Second, justification accords people meaningful rejection rights only if it idealizes less, rather than more, so as to place its bar for authoritativeness at readily accessible levels. Together, this conjures an image of protective justification practice that endows people with rejection rights that they can actually use to block what they see as unacceptable impositions. This sits well with what Forst seems to regard as part of the emancipatory upshot of RGA. In his view, justifications by RGA accord people a "qualified veto-right"34 that helps to protect them from unacceptable impositions, domination, or the disrespect that comes with it. Hence, each relevant person would here need standing of sufficient discursive purchase to be able to access and authentically and effectively exercise such a

33 For his purposes, Frankfurt seems to opt for a variant of maximalist sufficiency. Such a view would be unsuitable here. He writes that a person's holdings suffice when the person has enough; this, he explains, means that the person "is content, or that it is reasonable for him to be content, with having no more money than he has" (Frankfurt (1987), p. 37). Adapted to our case: Betty's standing has enough purchase when she is content, or it is reasonable for her to be content, to not have more normative influence in justification. But what makes people content? Some might not be content unless justification practice counts as authoritative all of their judgements-which leads back to problems of incoherence and anomy touched on above. If the issue is what it is reasonable to be content with, not much is gained if we (plausibly) take it that it is not reasonable to be content with a given level of purchase if it is impermissibly high or low.

34 Forst (2010), p. 719. 
veto-right. 35

\section{Impropriety Prohibited}

A fifth type of view focuses on purchase inequalities that stem from recognitive impropriety, widely conceived so as to include Fricker-type discriminatory epistemic injustices 36 involved in denying or diminishing others' status as knowers (or epistemic agents in the narrow sense of truth-seekers), and other forms of misrecognition involved in denying or diminishing their status as authoritative deliberators (or epistemic agents widely conceived as reason-givers, or co-authors of justification). Thus, consider Impropriety Prohibited (IP):

IP Purchase differentials within a justification practice are permissible if and only if they do not result from recognitive impropriety.

There are many ways in which recognitive impropriety can negatively impact an agent's or a group's ability to exert due normative influence in discursive practice. It may be instructive, then, to relate IP to Catala's view of hermeneutical domination. 37

Catala builds on Fricker's account of epistemic injustice, which focuses on testimonial and hermeneutical forms of epistemic injustice. Catala argues that testimonial injustices can lead dominant groups not only to hermeneutically marginalize non-dominant groups, thus exposing them to hermeneutical injustice, but also to impose on them putatively shared social meanings that they are unable to effectively contest-which subjects them to another kind of epistemic injustice, i.e., hermeneutic domination. 38 Testimonial injustice involves a wrongful denial of equal epistemic status. It occurs when an agent's claims are "wrongfully dismissed because of her membership in a particular social group." 39 For example, Betty wrongfully dismisses Paul's claims as not (equally, fully) credible because of his race, ethnicity, economic status, sexual orientation, and so on.

Testimonial injustice can lead to hermeneutical marginalization. A social group is so marginalized when "it participates unequally in the production of the descriptive labels that make up the society's collective hermeneutical resource," 40 its "shared tools of social interpretation," 41 or its "pool of understandings or available labels that individuals draw

\footnotetext{
35 To flesh out a variant of SN+(ii), and to specify necessary conditions of protective acceptability-based justification practice, I argue elsewhere that justifications should meet the requirement Authoritative Rejection Available (ARA). For a relevant agent $A$, relevant views $\phi$ that apply to $A$, and a relevant justification practice, JP, ARA requires JP to set its bar for authoritativeness at suitably low levels: if, upon consideration, $A$ cannot coherently accept $\phi$, then it should be a genuinely available option for $A$ to reject $\phi$ in ways that JP count as authoritative. ARA caps idealization values of authoritativeness thresholds and secures a minimum level of discursive purchase. When JP meets ARA, it recognizes relevant agents as self-authenticating sources of valid claims in the space of moral or political reasons. See Besch (2018b).

36 Fricker (2013), p. 1317.

37 Catala (2015), p. 427ff. To a similar effect, see Bohman (2012), pp. 179-184. See also Dieleman (2015).

38 See Catala (2015), pp. 427-432.

39 Ibid., p. 425, 428.

40 Ibid., p. $425 f$.

41 Fricker (2007), p. 6, 155.
} 
from and use to describe social practices and experiences." 42 This exposes group members to hermeneutical injustice. Hermeneutical injustice occurs when an agent's "social experience or interpretation is wrongfully misunderstood because of her social group's hermeneutical marginalization." 43 The agent thereby suffers an intelligibility deficit that puts her at an "unfair disadvantage" 44 when she tries to make her voice understood and recognized as intelligible in public discourse. Thus, hermeneutical domination can occur:

As a result of its unequal hermeneutical participation in the shaping of the public discourse of the practice, the minority is in effect hermeneutically disenfranchised by the majority. That is, the majority unilaterally imposes a collective understanding of the practice that is impossible for the minority to contest in any meaningful sense. 45

Let me generalize Catala's view beyond testimony in the narrow sense, or attempts to describe things or to communicate descriptive labels and factual experiences. This is on the view's trajectory. Identity prejudice can lead us to deny or diminish other's status not only as epistemic agents, but also as moral or political agents, as "self-authenticating sources of valid claims," 46 as reason-givers, as normative deliberators, and so forth. Accordingly, identity prejudice can lead a majority to wrongfully dismiss a minority's normative and evaluative claims, conceptions, or understandings as not (equally, fully) respectable, reasonable, or authoritative. And this can affect a society's hermeneutical resource (seen as also including non-descriptive 'tools of interpretation') in ways that marginalize and dominate a minority - thus putting its members at an unfair disadvantage when it comes to discursively bringing to bear their views as respectable, reasonable, or authoritative.

Recall, then, that justificatory reciprocity builds on some bar for authoritativeness. In relation to such bars, identity prejudice-or similar sources of recognitive impropriety-can take a toll in at least two ways. It can be in play when agents apply a bar for authoritativeness to others, given a conception of its content. For example, Betty wrongfully dismisses Paul's account of the meaning a social practice has for him, or considerations that reflect that meaning that he advances as reasons, as not authoritative (or not reasonable or respectable) because of his race, ethnicity, economic status, sexual orientation, and so on. Call this applicative discursive recognitive impropriety. It is applicative in the sense that identity prejudice is operative in the application, rather than the definition, of the norms of a justification practice. On the other hand, identity prejudice can be in play when members of a justification practice interpret, specify, revise, or adopt a bar for authoritativeness, or a conception of its content. For example, take again the problematically unequal justification practice JP4 that we saw earlier. Over time, persistent identity prejudice might have led members of JP4's Dominant Group to understand JP4's bar for authoritativeness in terms that privilege their own commitments at the expense of Marginal Group. We can call this constitutive discursive recognitive impropriety. It is constitutive in the sense that identity prejudice is operative in defining the norms of a justification practice, rather than in

42 Catala (2015), p. 425.

43 Ibid., p. 426.

44 Ibid.

45 Ibid., p. 429.

46 See Rawls (2001), p. 23; Besch (2018b). 
applying them, and it can resonate in such a justification practice even when deliberators apply its norms without recognitive impropriety of the first, applicative kind.

It is plain that applicative and constitutive discursive recognitive impropriety can impact discursive purchase, or the influence that relevant people can have in justification, or on its outcomes. This just is a key part of the unfair discursive disadvantages at which people are put when they suffer undue intelligibility deficits. According to IP, then, purchase inequalities are permissible only if they are not owed to these kinds of impropriety.

\section{Conclusion}

We have seen that there are various candidate conceptions of purchase justice that have at least some promise. And, of course, there can be other, perhaps no less plausible, candidates. For instance, I sidestepped entirely best results standards that would construe purchase inequality as permissible if it serves relevant best results, such as high levels of output respectability or input respectability. 47 Thus, if we ask whether a given allocation of discursive purchase is permissible or just, there is, or can be, a wide range of ostensibly different, and hence competing answers.

What to make of this? One conclusion surfaced earlier: purchase justice is a condition of justificatory reciprocity. It cannot be reasonable to use a standard like Forst's RGA as a standard of justification if that standard allocates discursive purchase in a manner that is impermissible, or unjust. At any rate, it seems that it cannot both be true that (i) $\phi$ is justified, or valid, in virtue of meeting RGA, and (ii) RGA allocates discursive purchase impermissibly, or unjustly. However, in any actual practice of justificatory reciprocityassuming that there are such practices-discursive purchase must be in a given allocation state. And if that practice (expectably) involves relevant interpersonal difference, it is likely to involve some level of purchase inequality. Hence, the presumption of the reasonableness of that practice, or its instantiation of justificatory reciprocity, commits to the substantive view that it satisfies purchase justice. In different terms: purchase justice is a substantive ethical commitment of justificatory reciprocity.

But does a given practice of justificatory reciprocity satisfy purchase justice? This question may not arise where differences in the meaningfulness of the normative say of relevant people have not become topical in their own right. Yet when it does arise, it cannot be answered simply by providing a rationale for justificatory reciprocity. The matter of purchase justice is more fundamental than this. Recall that we are concerned here with the participation value of justification. The focus is on the relationship between standards of justificatory reciprocity and the people they range over, or apply to. If this relationship is of the wrong kind, then justifications by such standards are defective. And if this relationship must satisfy purchase justice to be of the right kind, then purchase justice must be more fundamental in the order of justification than justifications by these standards.

It is plain, as well, that claims of purchase justice invite reasonable disagreement. There are, or can be, different conceptions of purchase justice; and so there are, or can be, different views as to what constitutes purchase justice in a given context, or in relation to a

47 Anti-constructivists sometimes opt for some such view. For example, in different ways, Arneson and Wall take it that if political principles must be authoritatively acceptable by relevant people, then the bar for authoritativeness must be set at a very high level that ensures that only those principles that truly should be accepted qualify as authoritatively acceptable. By implication, actual people merit no more normative influence in justification than is compatible with such best-results outcomes. See Arneson (2004), esp. pp. 4952; Wall (2016). 
given subject matter or situation type. However, if we disagree about whether a given standard of justificatory reciprocity satisfies purchase justice in a given context, then we disagree, as well, about whether meeting that standard can constitute justification, or validity, in that context. The point: such standards at best justify hypothetically, or conditionally, since they can provide justification only on the condition that they satisfy purchase justice.

Recall next that Forst requires reciprocal and general acceptability of all moral or political normative claims, including claims needed to specify or flesh out RGA (see Section 1 , above). Could he insist that views of purchase justice themselves depend for their validity on their reciprocal and general acceptability? In one sense, of course, this is not an option. It would get the order of justification backwards: the reasonableness of justificatory reciprocity depends on purchase justice, rather than vice versa. However, in another, more pragmatic and contextual sense, we might still try to justify a given view of purchase justice by a standard like RGA on the condition that this standard, in this application and context, satisfies purchase justice. But this must leave open what view of purchase justice we may adopt in the first place and for the purposes of that application and context. And what view is that? Considerations of reciprocal and general acceptability are only of limited use here. And this is troubling news for proponents of ideas of justificatory reciprocity.

Not least, let me relate questions of purchase justice to ordinary, first-order questions of distributive justice. The latter call for answers such as (for some good, $\alpha$ ):

A1 It is just to allocate $\alpha$ in manner $M$ because $M(\alpha)$ satisfies a principle (norm, standard, rule) of just distribution, $P$.

Assuming that P must meet a standard like Forst's RGA, A1 depends on a view such as:

A2 $M(\alpha)^{\prime}$ s justness should be assessed in light of $P$ since $P$ is valid: $P$, and not non-P, can equally be accepted authoritatively by all relevant people.

How should authoritativeness be conceived here? For simplicity's sake, I assume there are only two competing candidate authoritativeness thresholds, $\psi 1$ and $\psi 2$. This triggers:

Qi Should $M(\alpha)^{\prime}$ 's justness be assessed in light of its equal $\psi 1$-authoritative acceptability or its equal $\psi 2$-authoritative acceptability?

Much depends on our answer to Qi: A2 is reasonable only if it builds on a threshold it may build on, and if it is unreasonable, A1's reasonableness is in doubt. Now, considerations of purchase justice mark one dimension in which we can pick up Qi. Assuming, then, that $\psi 1$ and $\psi 2$ entail distinct patterns of purchase inequality, the question arises as to which pattern is permissible or just (or preferable). However, there are different conceptions of purchase justice, and they will provide different answers to this question. This triggers:

Qii On what view of purchase justice may we draw? (For example, should we draw on one of the candidates showcased above, or some other view?)

And here things get murky. It is not clear how we should answer Qii, or on what grounds we should prefer one conception of purchase justice over another. But what is clear is that a 
standard like RGA can help here only if the standard, in this iteration, satisfies purchase justice.

In closing, if these exploratory remarks make sense, then, of course, we might take them to suggest any of the following things:

(i) Moral or political justification should not model robust discursive equality.

(ii) If it should model robust discursive equality, then robust discursive equality should not be conceptualized in purchase-sensitive terms: formal discursive equality is all we can ask for.

(iii) We should not attach importance to the participation value of acceptabilitybased justification.

Proponents of justificatory reciprocity will not be inclined to draw these conclusionsrightfully so, I believe. But if we want to avoid such conclusions, we need to identify a plausible and defensible conception of purchase justice and conceptualize justificatory reciprocity in its terms.

Acknowledgements: For discussions of ideas included here or in earlier versions of this paper, I am indebted to Jung-Sook Lee, Ben Cross, Paul Patton, Robbie Arrell, Anke Thyen, Steven Wall, Uwe Steinhoff, as well as student groups at Wuhan University and attendees of the 2018 Public Reason Workshop at Wuhan University.

\section{References}

Arneson, Richard

2004 "Democracy is Not Intrinsically Just," in Justice and Democracy, edited by Keith Dowding, Robert E. Goodin, and Carole Pateman. Cambridge: Cambridge University Press, pp. 40-58.

Besch, Thomas $\mathrm{M}$.

2004 On Practical Constructivism and Reasonableness. PhD diss., University of Oxford.

Besch, Thomas M.

2012 "Political Liberalism, the Internal Conception, and the Problem of Public Dogma." Philosophy and Public Issues (New Series) 2(1): 153-177.

Besch, Thomas $\mathrm{M}$.

2014 "On Discursive Respect." Social Theory and Practice 40(2): 207-231.

Besch, Thomas $\mathrm{M}$.

2015 "On the Right to Justification and Discursive Respect." Dialogue: Canadian Philosophical Review 54(4): 703-726.

Besch, Thomas M.

2018a "Public Justification, Inclusion, and Discursive Equality." Dialogue: Canadian Philosophical Review 57(3): 591-614.

Besch, Thomas M.

2018b "On Justification, Idealization, and Discursive Purchase." Philosophia, doi: $10.1007 / \mathrm{s} 1140601800075$.

Besch, Thomas $\mathrm{M}$. 
2018c "A Note on Reciprocity of Reasons." Manuscript. Available at: https://www.academia.edu/35240723/A_note_on_reciprocity_of_reasons.

Bohman, James

2006 "Deliberative Democracy and the Epistemic Benefits of Diversity." Episteme 3(3): 175-191.

Bohman, James

2012 "Domination, Epistemic Injustice and Republican Epistemology." Social Epistemology 26(6): 175-187.

Catala, Amandine

2015 "Democracy, Trust, and Epistemic Justice." The Monist 98(4): 424-440.

Cohen, Joshua

2006 "Is there a Human Right to Democracy?," in The Egalitarian Conscience: Essays in Honour of G.A. Cohen, edited by Christine Sypnowich. Oxford: Oxford University Press, pp. 226-248.

Dieleman, Susan

2015 “Epistemic Justice and Democratic Legitimacy." Hypatia 30(4): 794-810.

Enoch, David

2015 "Against Public Reason," in Oxford Studies in Political Philosophy, Vol. 1, edited by David Sobel, Peter Vallentyne, and Steven Wall. Oxford: Oxford University Press, pp. 112-144.

Forst, Rainer

2001 "Toward a Critical Theory of Transnational Justice." Metaphilosophy 32(2): 160-179.

Forst, Rainer

2010 "The Justification of Human Rights and the Basic Right to Justification: A Reflexive Approach." Ethics 120(4): 711-740.

Forst, Rainer

2011 "The Grounds of Critique: On the Concept of Dignity in Social Orders of Justification." Philosophy and Social Criticism 37(9): 965-976.

Forst, Rainer

2012 The Right to Justification. New York: Columbia University Press.

Forst, Rainer

2017 Normativity and Power. Oxford: Oxford University Press.

Frankfurt, Harry

1987 "Equality as a Moral Ideal." Ethics 98(1): 21-43.

Frankfurt, Harry

2015 On Inequality. Princeton: Princeton University Press.

Fricker, Miranda

2007 Epistemic Injustice. Oxford: Oxford University Press.

Fricker, Miranda

2013 "Epistemic Justice as a Condition of Political Freedom?" Synthese 190(7): 1317-1332.

Gosepath, Stefan

2015 "On the (Re)Construction and Basic Concepts of the Morality of Equal Respect," in Do All Persons Have Equal Moral Worth?, edited by Uwe Steinhoff, Oxford: Oxford University Press, pp. 124-141.

Karpowitz, Christopher F., and Chad Raphael 
2016 "Ideals of Inclusion in Deliberation." Journal of Public Deliberation 12(2): Article 3.

Larmore, Charles

2015 "Political Liberalism: Its Motivation and Goals," in Oxford Studies in Political Philosophy, Vol. 1, edited by David Sobel, Peter Vallentyne, and Steven Wall. Oxford: Oxford University Press, pp. 63-87.

Macedo, Stephen

1991 Liberal Virtues. Oxford: Clarendon Press.

Mandle, Jon

1999 "The Reasonable in Justice as Fairness." Canadian Journal of Philosophy 29(1): 75-108.

Nagel, Thomas

2005 "The Problem of Global Justice." Philosophy and Public Affairs 33(2): 113-147. Postema, Gerald J.

1995 "Public Practical Reasoning: An Archeology." Social Philosophy and Policy 12(1): 43-86

Rawls, John

1972 A Theory of Justice. Oxford: Oxford University Press.

Rawls, John

2001 Justice as Fairness: A Restatement. Edited by Erin Kelly. Cambridge (MA): Belknap Press.

Rawls, John

2005 Political Liberalism. New York: Columbia University Press.

Rousseau, Jean-Jacques

1988 Rousseau's Political Writings. Edited by Alan Ritter and translated by J.C. Bondanella. New York: Norton.

Steinhoff, Uwe

2015 "Against Equal Respect and Concern, Equal Rights, and Egalitarian Impartiality," in Do All Persons Have Equal Moral Worth?, edited by Uwe Steinhoff. Oxford: Oxford University Press, pp. 142-172.

Talisse, Robert

2007 A Pragmatist Philosophy of Democracy. New York: Routledge.

Wall, Steven

2016 "The Pure Theory of Public Justification." Social Philosophy and Policy 32(2): 204-226. 